\title{
Business, Innovation, and Knowledge Ecosystems: How They Differ and How to Survive and Thrive within Them
}

\author{
Katri Valkokari
}

\author{
"How dreadful... to be caught up in a game and have no idea") \\ of the rules.
}

\author{
Caroline Stevermer \\ In Sorcery \& Cecelia or The Enchanted Chocolate Pot
}

\begin{abstract}
In management studies, the ecosystem metaphor is often utilized without clear definition and, thereby, several partially overlapping concepts such as industrial, business, service, innovation, and knowledge ecosystems have been introduced. The purpose of this conceptual article is to go beyond the confusion to define what is meant by different concepts regarding an ecosystem and especially describe the relationships between the three different ecosystem types: business, innovation, and knowledge ecosystems. The article contributes to the literature by describing how the ecosystem types differ in terms of their outcomes, interactions, logic of action, and actor roles. The results show that the three ecosystem types are interconnected from the viewpoint of the ecosystem actor. For practitioners, the article sheds more light on how the rules of the game (i.e., the logic of action) differ in the different types of ecosystems and demonstrates that different models are needed in order to operate in different ecosystems.
\end{abstract}

\section{Introduction}

The scope of ecosystem science extends from bounded systems such as watersheds to spatially complex landscapes, even to the Earth itself. Furthermore, research into biological ecosystems crosses temporal scales from seconds to millennia and links together several disciplines of biology. The ecosystem concept dates back to 1930 and, at various times, ecology researchers have focused on different aspects of its meaning (Willis, 1997). Social science has approached the economy as an ecosystem (Rothschild, 1990), viewing the global economy as an entity in which organizations and consumers are the living organisms. Starting from its (re)introduction two decades ago by Moore (1996), the ecosystem concept has also been actively discussed in management studies, bridging, for instance, system thinking and evolutionary economics. In management studies, a primary motivation for utilizing ecosystem concepts has been the desire to exploit self-organizing properties of natural ecosystems (Briscoe \& Sadedin, 2007). Still, there are at least two drawbacks constraining the ap- plication of biological metaphors to research on economic activities: the intentionality of human activities and the possibility for actors in economic ecosystems to interbreed (Corallo \& Propata, 2007). Both drawbacks are characteristic of man-made ecosystems and can, therefore, be utilized to describe the differences between ecosystem types. In management studies, meta-organizations such as ecosystems have been approached with different concepts (Gulati et al., 2012) and, previously, research has typically focused on one of the ecosystems only, when in the real-world systems the interest of actors (i.e., organisations) who are the ecosystem inhabitants and come bundled together with multiple parts (Muegge, 2013). Furthermore, institutional factors - the set of both formal and informal constraints, and enforcement characteristics that structure interactions - associated with participation is scarcely researched (Muegge, 2011; Smith, 2013). Thus, relationships and interactions between ecosystems types need to be analyzed at several levels in order to understand how connections flow between different ecosystems in the real business world. 


\section{Business, Innovation, and Knowledge Ecosystems}

\section{Katri Valkokari}

The natural as well as the man-made ecosystem is always unique - each ecosystem consists of a unique set of actors and interactions and thereby evolves in its own manner. In an ecosystem, each actor has their own role to play and, in this way, they view the partially overlapping ecosystems from their own unique perspective. Thus, as proposed by Weber and Hine (2015), rather than focusing on ecosystems as platforms, a model should be explored where ecosystems are viewed as structures of and relationships between interacting actors. The decisions and the related actions that are taken throughout the evolution of an ecosystem also shape its present and future state, as each decision provides raw material for subsequent decisions (David, 1985; Valkokari \& Valkokari, 2014). Thus, ecosystems are dynamically evolving through interactions between ecosystem actors and should not be perceived from a deterministic or linear viewpoint (Wallner \& Menrad, 2011). Furthermore, the economic ecosystem may consist of both networks of multiple firms and individuals, who are participating through different interaction mechanisms. Within management and innovation studies, there are several partially overlapping concepts such as business, innovation, and knowledge ecosystems - to describe the meta-organizations between economic actors. This article sheds more light on how the different ecosystem types differ from each other in terms of their outcomes, interactions, logic of action, and actor roles. The purpose of this conceptual article is to clear up the confusion and define what is meant by the different concepts regarding an ecosystem, and especially to describe the relationships between the different ecosystem types. For practitioners, the article explains how the logic of action, or "the rules of the game", differ in the different types of ecosystems.

To attain this goal, the rest of the article is structured as follows. The next section reviews the research on ecosystems in management studies. Then, the relationships between different ecosystem types are discussed. Finally, the theoretical contribution is presented, together with the practical implications and an evaluation of the research and recommendations for further research.

\section{Making Sense of Ecosystem Concepts}

The system boundary definition is crucial for making sense of ecosystems (Gulati et al., 2012; Korhonen \& Snäkin, 2005; Post et al., 2007). Thus, system boundaries can be set in several ways: by geographical scope (local vs. regional or national vs. global), by temporal scale (from history to future or static snapshots vs. dynamic interactions), by permeability (open vs. closed), as well as by types of flows (knowledge, value, material), which must be decided upon. In this conceptual article, the differentiation between the ecosystem concepts is based on the type of flow, which can also be approached as a shared intention or a baseline and outcome for each ecosystem as well as describing the cause of interbreeding within the ecosystem (Corallo \& Propata, 2007). In other words, through interbreeding, ecosystem actors are able to constantly produce new outcomes by combining artefacts, skills, and ideas, and these different business, knowledge, and innovation outcomes distinguish the ecosystems from each other. Thus, Post and colleagues (2007) pointed out that space and time are intimately linked in any discussion of ecosystem boundaries; therefore, the geographical and temporal scales of ecosystems are also discussed in this article.

Three different economic ecosystem types are distinguished in this article. First, in the literature of business ecosystems as well as service or industrial ecosystems, the economic outcomes and business relationships between actors are highlighted. Second, the discussion of innovation (eco)systems and regional clusters focus on mechanism and policies fostering the creation of innovative startups around so-called regional hubs or clusters. Third, knowledge ecosystems have their main interest and outcome in creation of new knowledge through joint research work, collaboration, or the development of knowledge base.

In line with Moore (1996), the business ecosystem is here defined as "an economic community supported by a foundation of interacting organizations and individuals - the organisms of the business world". The strategic management literature focuses on business ecosystems as sources of competitive advantage for individual companies (Adner, 2012; Iansiti \&Levien, 2004) and therefore the keystone and niche player have been defined as two key roles for companies in an ecosystem (Carbone, 2009; Smith, 2013). Thus, a shift of what is valued drives the need for the different models and reflects the terminology utilized in business ecosystem literature. Recently, within the emergence of service-dominant logic (S-D Logic) (Vargo \& Lusch, 2011) and digital services (Thomas et al., 2014), the concept of service ecosystems has also been introduced. In this way, the dyadic or triadic collaboration between actors, and especially between customer and service provider, is highlighted. Furthermore, the concept of industrial 


\section{Business, Innovation, and Knowledge Ecosystems}

\section{Katri Valkokari}

ecosystems is connected to industrial symbiosis, focusing on the relations among companies in a direct waste/by-product exchange (e.g., Baas, 1998) or focusing on industrial parks (Côté \& Hall, 1995).

Despite using the ecosystem concept, in several cases there is more a question of a (strategic) partnership between a platform owner (or a focal firm) and a provider of complementary assets. Thus, within the business ecosystem approach, in the same way as business (Halinen \& Törnroos, 2005) or value (Allee, 2002) networks, the business ecosystem can be seen as a group of companies and other organizations, which simultaneously creates and captures value by combining its resources, while it operates around a focal firm or is linked to a platform (Milinkovich, 2008). The variety of actors is the major difference between the concepts of business networks and ecosystems, which are typically considered to include more actors than a network (Heikkilä \& Kuivaniemi, 2012). As described already by Moore (1993), a business ecosystem is composed of several layers, which correspond to differing levels of commitment to the business. The ecosystem's core business layer consists of the parties forming the heart of the business: the business network actors such as suppliers, a focal firm, distributors, and customers.

In addition to industrial parks, clusters are also actively discussed within the concepts of innovation or knowledge ecosystems. The concept of industrial clusters, originally proposed by Porter (1990), highlights the competitive advantage at the regional level. Depending on the author, the basic idea of a cluster is either concentration and locality, or regionalism (Peltoniemi, 2004). The discussion has explored the mechanisms by which geographically clustered organizations benefit from their locations and collaboration (Almeida \& Kogut, 1999; Claryssen et al., 2014; Coughlan, 2014). The main outcome of a knowledge ecosystem is new knowledge, and it could be shaped by pointing out the network nodes where the knowledge is created and retained (Quin et al., 1998). In other words, the main focus is exploration instead of exploitation. Open source communities are a well-known example of this ecosystem type based on knowledge exchange (Koening, 2012) and therefore recent research highlights how colocation can also mean virtual proximity, like emotional closeness, between the actors (Coughlan, 2014). On the other hand, the innovation ecosystem approach emphasizes fostering the creation of growth, interaction, and innovative startups around so-called knowledge hubs (Engel \& del Palacio, 2011). For instance,
Silicon Valley is often utilized as an example of success. Thus, within the innovation ecosystem, the financial network that supports the actors (both companies and research institutes and other technology developers) has recently been identified as one of the key success factors (Claryssen et al., 2014). There is an active discussion of value co-creation within boundary-spanning innovation and several concepts, such as "collaborative", "democratized", "open", "networked" or "co-“ innovation have been introduced (Lee et al., 2012) and at least the technology-intensive business organizations, from specialized startups to diversified multinational enterprises, increasingly participate within ecosystems in different roles such as adopters and patrons of open platforms, and stewards and promoters of innovation communities (Muegge, 2011).

To sum up, in the real-world, present-day ecosystems are global and setting the ecosystem borders is a complicated issue. Still, studies of innovation or knowledge ecosystems have omitted this global dimension and focused on regional - geographically proximate - actors. In other words, regarding the geographical borders, the local ecosystem, such as a coral reef, is a sub-system of a broader ecosystem, a water system like a sea, and the changes in the broader system also have a growing influence in man-made ecosystems due to globalization, the development of information and communication technology, and deregulation. On the other hand, the changes inside the sub-systems also influence the emergence of changes in the "main" system and, thereby, the impacts are connected to the temporal borders between ecosystems. Anyhow, the question that often remains unresolved is how to develop mutually beneficial ecosystems, rather than "winner takes all" marketplaces or technology platforms, whose dominant players set the terms of coordination, collaboration, and competition.

\section{Relationships Between the Ecosystem Types}

There is different logic of action in the different ecosystem types (Claryssen et al., 2014) and the same actor can be involved and play different roles in each ecosystem (Figure 1). From the viewpoint of each individual actor, the interaction area between the ecosystem types and their relationships are different. Thus, highly mobile actors, platform owners, or keystone companies are examples of actors boosting the interaction between the ecosystem types. On the other hand, a platform - an organization of things such as technologies or complementary assets (Muegge, 2013) - also may be 


\section{Business, Innovation, and Knowledge Ecosystems}

\section{Katri Valkokari}

the interconnecting factor between the ecosystems. Because of these interconnectivity actors and platforms, ecosystems do interact with each other and therefore are evolving and emerging next to each other. Furthermore, there are both dyadic and triadic interactions between the different types of ecosystem, as indicated in Figure 1.

Table 1 summarizes the differences between the three ecosystem types in terms of their outcomes, interactions, actor roles, and logic of action. Business ecosystems focus on present customer value creation, and the large companies are typical key players within them. Knowledge ecosystems focus on the generation of new knowledge, and in this way research institutes and innovators, such as technology entrepreneurs, play a central role in these ecosystems. Innovation ecosystems occur as an integrating mechanism between the exploration of new knowledge and its exploitation for value co-creation in business ecosystems. Thus, innovation policymakers, local intermediators, innovation brokers, and funding organizations (such as venture capitalists or public funding agencies) are salient actors in innovation ecosystems.
All these ecosystems are dynamic, changing, and also changeable through ecosystem orchestration. Different organisms (i.e., species in natural ecosystems or actors with complementary roles in man-made ecosystems) are necessary to keep the ecosystem balanced, and removing one can cause a chain reaction felt throughout the entire ecosystem. Biological ecosystems are characterized by one or more equilibrium states, where a relatively stable set of conditions exist and maintain a population or nutrient exchange at particular levels. It is, however, important to note that the equilibrium of biological ecosystems is seldom optimal from the viewpoint of all species in the ecosystem. Thus, an ecosystem always induces both competition and cooperation, which leads to the selection and adaption of species. And, despite hitherto mainly positive approaches to man-made ecosystems, which have typically perceived ecosystems as positive and collaborative systems, that is also true within business, knowledge, and innovation ecosystems. Furthermore, ecosystems are often considered from a rather deterministic and linear viewpoint. According to Wallner and Menrad (2011), this linear view is focused on input factors that are supposed to directly influence outcomes, although "an ecosystem

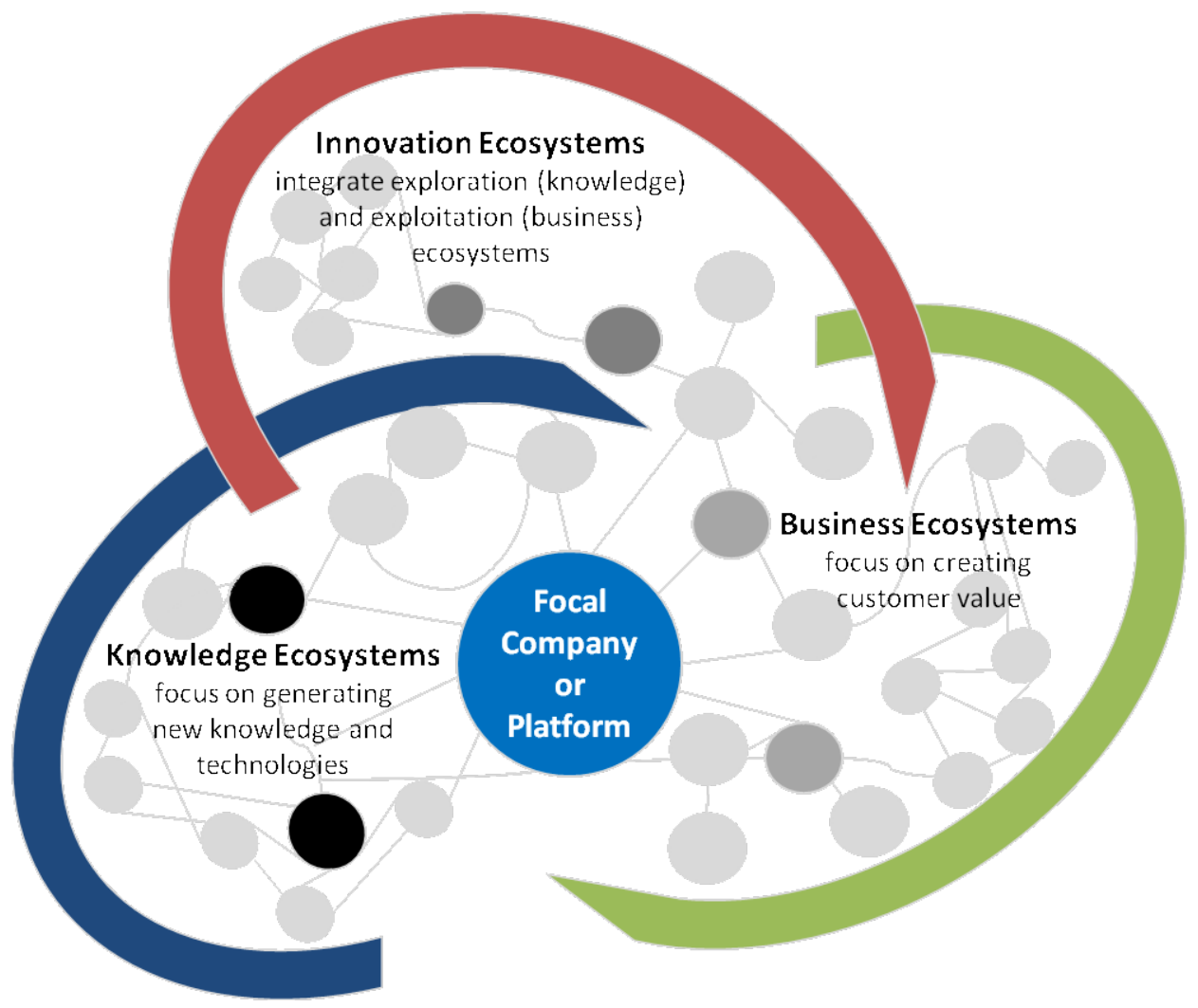

Figure 1. Relationships between overlapping ecosystem types 


\section{Business, Innovation, and Knowledge Ecosystems}

\section{Katri Valkokari}

Table 1. Characteristics of ecosystem types

\begin{tabular}{|c|c|c|c|}
\hline & Business Ecosystems & Innovation Ecosystems & Knowledge Ecosystems \\
\hline Baseline of Ecosystem & $\begin{array}{l}\text { Resource exploitation for } \\
\text { customer value }\end{array}$ & Co-creation of innovation & Knowledge exploration \\
\hline $\begin{array}{l}\text { Relationships and } \\
\text { Connectivity }\end{array}$ & $\begin{array}{l}\text { Global business relationships } \\
\text { both competitive and co- } \\
\text { operative }\end{array}$ & $\begin{array}{l}\text { Geographically clustered } \\
\text { actors, different levels of } \\
\text { collaboration and openness }\end{array}$ & $\begin{array}{l}\text { Decentralized and disturbed } \\
\text { knowledge nodes, synergies } \\
\text { through knowledge exchange }\end{array}$ \\
\hline Actors and Roles & $\begin{array}{l}\text { Suppliers, customers, and focal } \\
\text { companies as a core, other } \\
\text { actors more loosely involved }\end{array}$ & $\begin{array}{l}\text { Innovation policymakers, local } \\
\text { intermediators, innovation } \\
\text { brokers, and funding } \\
\text { organizations }\end{array}$ & $\begin{array}{l}\text { Research institutes, innovators, } \\
\text { and technology entrepreneurs } \\
\text { serve as knowledge nodes }\end{array}$ \\
\hline Logic of Action & $\begin{array}{l}\text { A main actor that operates as a } \\
\text { platform sharing resources, } \\
\text { assets, and benefits or } \\
\text { aggregates other actors } \\
\text { together in the networked } \\
\text { business operations }\end{array}$ & $\begin{array}{l}\text { Geographically proximate } \\
\text { actors interacting around hubs } \\
\text { facilitated by intermediating } \\
\text { actors }\end{array}$ & $\begin{array}{l}\text { A large number of actors that } \\
\text { are grouped around knowledge } \\
\text { exchange or a central non- } \\
\text { proprietary resource for the } \\
\text { benefit of all actors }\end{array}$ \\
\hline
\end{tabular}

is not a trivial machine, with a defined input-output ratio". Thus, as distinct from biological ecosystems, some level of intentional organizing exists in man-made ecosystems: it shapes the attraction, selection, and retention of members of the ecosystem. The world of practice has been changing dramatically in a direction that places ever greater importance on coordination beyond the boundaries of the firm (Gulati et al., 2012; Muegge, 2013; Valkokari \& Valkokari, 2014). Ecosystem actors have several reasons to stay together or actively participate in the orchestration of their ecosystem. The ecosystem inhabitants are unique entities based on their organizational routines, capabilities, and use of technology (Weber \& Hine, 2015). Thus, the level of interaction and interdependencies in man-made ecosystems are multidimensional as the system-level goals bring actors close together. As biological ecosystems, these organisms coexist, collaborate, and coevolve via a complex set of symbiotic and reciprocal relationships, which together form a larger ecosystem. Interaction between the ecosystem actors strengthens the dependencies between them. Thus, the dependencies between the ecosystem participants are important influences on outcomes, success, and mobilization within an ecosystem (Adner \& Kapoor, 2010).

The business ecosystem has been established around value co-creation and capture: the direct business benefits of ecosystem actors. Typically, the actors operate around a focal firm or are linked to a platform. If the ecosystem has a shared platform that acts as its locus of coordination, then platform technological features also have an important influence on ecosystem evolution (Iansiti \& Levien, 2004; Thomas et al., 2014). The mobile ecosystems configured around dominant market players such as Apple, Samsung, and Nokia, and competition between them is a well-known example of business ecosystems. The variety of complementary resources is another important aspect in business ecosystems. Furthermore, counterpointing knowledge lays the foundations for knowledge ecosystems especially. The ecosystem is constituted from both providers and consumers that benefit from the interaction and are thereby intertwined together through even symbiotic relationships. In innovation ecosystems, intermediators play an important role in bridging the actors together and thereby facilitating interaction and building dependencies between them. In other words, it can be said that intermediators themselves form a platform in innovation ecosystems. In addition, on a temporal scale, the future-orientation of innovation ecosystem contrasts with the other concepts.

\section{Conclusion}

The way we perceive the business world around us is affected by our own experiences and is developed through sense-making from various models originating from management consulting or academic publications. The aim of this article was to define what is 


\section{Business, Innovation, and Knowledge Ecosystems}

\section{Katri Valkokari}

meant by different concepts regarding an ecosystem in management studies and especially describe the relationships between the three different ecosystem types: business, innovation, and knowledge ecosystems. The article contributed to the discussion by summarizing the differences and logic of action in the three ecosystem types. For practitioners, the paper sheds more light on the rules of the game required in living in and orchestrating different ecosystem types. Thus, an ecosystem approach anchored around understanding its inhabitants (i.e. actors, their roles, and their relationships) offers information that can be practically applied (Weber \& Hine, 2015). In order to survive and thrive in an ecosystem, the essential point is to understand that different forms of interaction are required in different ecosystems.

Although formal authority is invisible in man-made ecosystems, this research highlights that they are not entirely self-organized: they are organizational designs that are held together on the condition that their members are in formal or informal agreement about shared purpose (baseline) and operation modes (logic of action). Still, understanding the coordination mechanism and its evolution over time is important, both for strategic decision making and the orchestration of ecosystems as well as building roadmaps for their future evolution. First, business ecosystems focus on present customer value creation, and large companies are typical key players within them. Second, knowledge ecosystems focus on the generation of new knowledge, and research institutes and innovators, such as technology entrepreneurs, play a central role in these ecosystems. Third, innovation ecosystems occur as an integrating mechanism between the exploration of new knowledge and its exploitation for value co-creation in business ecosystems. The relationships and the dynamics between overlapping ecosystems is an important research theme, and we need to create tools to enable crossing borders between the ecosystems. Therefore, food webs may provide a powerful framework for further research addressing the infrastructure that link population dynamics (actors) and community structure (relationships) to ecosystem function because they can represent both species interactions within a community and energy flow through those species (Post et al., 2007). On the other hand, an engrossing avenue for further research is the emergence of an ecosystem, because researchers and practitioners tend to assume that the ecosystems already exist and the temporal dimensions remains un-researched. Within this research theme, we could also benefit from the research of dispersion in biological ecosystems.

To conclude, scholarly work on the various forms of multi-actor assemblages is largely disconnected and shows only few signs of convergence (Gulati et al., 2012; Muegge, 2013). Although the authors with different roots utilize different ecosystem concepts, they agree that further research is needed in order to investigate more thoroughly the mechanisms and rules governing the interaction within ecosystems (Koening, 2012). In particular, the interaction between the different types of ecosystem is an unexplored area, and also further empirical research is needed to explore how ecosystem actors perceive their concurrent roles in different ecosystems.

\section{Acknowledgements}

The author would like to thank both the anonymous reviewer and the editor; their comments helped to clarify the focus and implications of the article. The research work is part of the research program "Towards Relational Business Practices" (REBUS), which is one of the research programs of the Finnish Metals and Engineering Competence Cluster (FIMECC).

\section{About the Author}

Katri Valkokari works as a Principal Scientist at VTT (Technical Research Centre of Finland) in the Business Ecosystems, Value Chains and Foresight research area. Over the past 15 years, she has carried out several development projects concerning different networked business arrangements (ecosystems, networks, partnerships, and firms). In 2009, Katri completed her doctoral thesis on business network development. She has published several international and national articles in the research areas of business network management, collaboration, organizational knowledge, and innovation management. 


\section{Business, Innovation, and Knowledge Ecosystems}

\section{Katri Valkokari}

\section{References}

Adner, R., \& Kapoor, R. 2010. Value Creation in Innovation Ecosystems: How the Structure of Technological Interdependence Affects Firm Performance in New Technology Generations. Strategic Management Journal, 31(3): 306-333. http://dx.doi.org/10.1002/smj.821

Adner, R. 2012. The Wide Lens: A New Strategy for Innovation. Penguin Books Ltd.

Baas, L. 1998. Cleaner Production and Industrial Ecosystems: A Dutch Experience. Journal of Cleaner Production, 6 (3-4): 189-197. http://dx.doi.org/10.1016/S0959-6526(98)00015-8

Briscoe, G., \& Sadedin, S. 2007. Natural Science Paradigms. In F. Nachira, A. Nicolai, P. Dini, L. Rivera Lèon, \& M. Louarn (Eds.), Digital Business Ecosystems: The Results and the Perspectives of the Digital Business Ecosystem Research and Development Activities in FP6: 48-55. Luxembourg: European Commission.

Carbone, P. 2009. The Emerging Promise of Business Ecosystems. Open Source Business Resource, February 2009: 11-16. http://timreview.ca/article/227

Clarysse, B., Wright, M., \& Bruneel, J. 2014. Creating Value in Ecosystems: Crossing the Chasm between, Knowledge and Business Ecosystems. Research Policy, 43(7): 1164-1176. http://dx.doi.org/10.1016/j.respol.2014.04.014

Côté, R. P., \& Hall, J. 1995. Industrial Parks as Ecosystems. Journal of Cleaner Production, 3(1-2): 41-46. http://dx.doi.org/10.1016/0959-6526(95)00041-C

Corallo, A., \& Protopapa, S. 2007. Business Networks and Ecosystems: Rethinking the Biological Metaphor. In F. Nachira, A. Nicolai, P. Dini, L. Rivera Lèon, \& M. Louarn (Eds.), Digital Business Ecosystems: The Results and the Perspectives of the Digital Business Ecosystem Research and Development Activities in FP6: 60-64. Luxembourg: European Commission.

Coughlan, T. 2014. Enhancing Innovation through Virtual Proximity. Technology Innovation Management Review, 4(2): 17-22. http://timreview.ca/article/765

David, P. A. 1985. Clio and the Economics of QWERTY. The American Economic Review, 75(2): 332-337.

Engel, J. S., \& del Palacio, I. 2011. Global Clusters of Innovation: The case of Israel and Silicon Valley. California Management Review, 53 (2): $27-49$.

Gulati, R., Puranam, P., \& Tushman, M. L. 2012. Meta-Organization Design: Rethinking Design in Interorganizational and Community Contexts. Strategic Management Journal, 33(6): 571-586. http://dx.doi.org/10.1002/smj.1975

Halinen, A., \& Törnroos, J.-Å. 2005. Using Case Methods in the Study of Contemporary Business Networks. Journal of Business Research, 58(9): 1285-1297.

http://dx.doi.org/10.1016/j.jbusres.2004.02.001

Heikkilä, M., \& Kuivaniemi, L. 2012. Ecosystem Under Construction: An Action Research Study on Entrepreneurship in a Business Ecosystem. Technology Innovation Management Review, 2(6): $18-24$.

http://timreview.ca/article/564
Iansiti, M., \& Levien, R. 2004. The Keystone Advantage: What the New Dynamics of Business Ecosystems Mean for Strategy, Innovation, and Sustainability. Boston, MA: Harvard Business School Press.

Koening, G. 2012. Business Ecosystems Revisited. M@n@gement, 15(2): 208-224.

Korhonen, J., \& Snäkin, J.-P. 2005. Analysing the Evolution of Industrial Ecosystems: Concepts and Application. Ecological Economics, 52(2):169-186. http://dx.doi.org/10.1016/j.ecolecon.2004.07.016

Lee, S. M., Olson, D. L., \& Trimi, S. 2012. Co-Innovation: Convergenomics, Collaboration, and Co-Creation for Organizational Values. Management Decision, 50(5): 817-831. http://dx.doi.org/10.1108/00251741211227528

Milinkovich, M. 2008. TIM Lecture Series: A Practitioners Guide to Ecosystem Development. Open Source Business Resource, October 2008: 40-42. http://timreview.ca/article/200

Moore, J. F. 1993. Predators and Prey: A New Ecology of Competition. Harvard Business Review, May/June 1993: 75-86.

Moore, J. F. 1996. The Death of Competition: Leadership and Strategy in the Age of Business Ecosystems. New York, NY: HarperBusiness.

Muegge, S. 2011. Business Ecosystems as Institutions of Participation: A Systems Perspective on Community-Developed Platforms. Technology Innovation Management Review, 1(2): 4-13. http://timreview.ca/article/495

Muegge, S. 2013. Platforms, Communities, and Business Ecosystems: Lessons Learned about Technology Entrepreneurship in an Interconnected World. Technology Innovation Management Review, 3(2): 5-15. http://timreview.ca/article/655

Peltoniemi, M. 2004. Cluster, Value Network and Business Ecosystem: Knowledge and Innovation Approach. Paper presented at the Conference on Organisations, Innovation and Complexity: New Perspectives on the Knowledge Economy, September 9-10, Manchester, UK.

Porter, M. 1990. Competitive Advantage of Nations. London: Macmillan.

Post, D., Doyle, M., Sabo, J., \& Finlay, J. 2007. The Problem of Boundaries in Defining Ecosystems: A Potential Landmine for Uniting Geomorphology and Ecology. Geomorphology, 89 (102): 111-126. http://dx.doi.org/10.1016/j.geomorph.2006.07.014

Quinn, J. B., Anderson, P., \& Finkelstein, S. 1998. New Forms of Organizing. In H. Mintzberg \& J.B. Quinn (Eds.), Readings in the Strategic Process: 362-374. Upper Saddle River, NJ: Prentice Hall.

Rotschild, M. 1990. Bionomics: Economy as Ecosystem. New York: Henry Holt and Company.

Ross, N., Eyles, J., Cole, D., \& Innantuono, A. 1997.The Ecosystem Health Metaphor in Science and Policy. The Canadian Geographer, 41(2): 114-127.

Smith, D. 2013. Navigating Risk When Entering and Participating in a Business Ecosystem. Technology Innovation Management Review, 3(5): 25-33.

http://timreview.ca/article/685 


\section{Business, Innovation, and Knowledge Ecosystems}

\section{Katri Valkokari}

Thomas, L. D. W., Autio, E., \& Gann, D. M. 2014. Architectural Leverage: Putting Platforms in Context. Academy of Management Perspectives, 28(2): 198-219.

http://dx.doi.org/10.5465/amp.2011.0105

Wallner, T., \& Menrad, M. 2011. Extending the Innovation Ecosystem Framework. In Proceedings of XXII ISPIM Conference. Hamburg, Germany.

Vargo, S.L ., \& Lusch, R. F. 2011. It's All B2B... and Beyond: Toward a Systems Perspective of the Market. Industrial Marketing Management, 40(2): 181-187.

http://dx.doi.org/10.1016/j.indmarman.2010.06.026
Valkokari, K., \& Valkokari, P. 2014. How SMEs Can Manage Their Networks - Lessons Learnt from Communication in Animal Swarm. Journal of Inspiration Economy, 1(1): 111-128.

Weber, M. L., \& Hine, M. J. 2015. Who Inhabits a Business Ecosystem? The Technospecies as a Unifying Concept. Technology Innovation Management Review, 5(5): 31-44. http://timreview.ca/article/896

Willis, A. J. 1997. The Ecosystem: An Evolving Concept. Functional Ecology, 11(2): 268-271.

http://dx.doi.org/10.1111/j.1365-2435.1997.00081.x

Citation: Valkokari, K. 2015. Business, Innovation, and Knowledge Ecosystems: How They Differ and How to Survive and Thrive within Them. Technology Innovation Management Review, 5(8): 17-24. http://timreview.ca/article/919

Keywords: business ecosystem, innovation ecosystem, knowledge ecosystem, man-made ecosystem, ecosystem, platforms, communities, conceptual paper, logic of action 